\section{Dermal irritation study of Pankajakasthuri orthoherb cream/thermagel, a potent polyherbal anti-inflammatory and analgesic formulation for topical application in healthy New Zealand white rabbits}

\section{Hareendran Nair J, Shan Sasidharan}

${ }^{1}$ Department of Research and Development, Pankajakasthuri Herbal Research Foundation,Pankajakasthuri Ayurveda Medical College Campus, Killy, Kattakada, Thiruvananthapuram, Kerala, India

\begin{abstract}
Pankajakasthuri orthoherb cream/thermagel is a polyherbal topical medication formulated for managing inflammation and pain. The objective of the present study was to evaluate the skin irritation potential of Pankajakasthuri orthoherb cream/thermagel on a single and repeated application in New Zealand white rabbits. The rabbits were dermally exposed with Pankajakasthuri orthoherb cream/thermagel and the appearance of each application site at $1 \mathrm{~h}, 24 \mathrm{~h}, 48$ $\mathrm{h}, 72 \mathrm{~h}, 7^{\text {th }}$ day and $14^{\text {th }}$ day was recorded. The dermal reactions (erythema and edema) were evaluated according to the skin reactions scoring system. Pankajakasthuri orthoherb cream/thermagel did not induce any reactions on intact skin sites after its application and following 14-day observation period in a single exposure test. In repeated exposure studies, application of Pankajakasthuri orthoherb cream/thermagel in the intact skin resulted in the formation of erythema and edema in some animals. However, $72 \mathrm{~h}$ after final
\end{abstract}

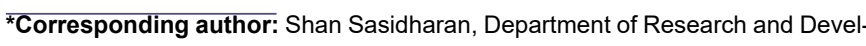
opment, Pankajakasthuri Herbal Research Foundation, Pankajakasthuri Ayurveda Medical College Campus, Killy, Kattakada, Thiruvananthapuram, Kerala, India, E-mail: drshansasidharan@yahoo.co.in/drshan@pkhil.com

Citation: Nair JH, Sasidharan S (2021) Dermal irritation study of Pankajakasthuri orthoherb cream/thermagel, a potent polyherbal antiinflammatory and analgesic formulation for topical application in healthy New Zealand white rabbits. J Toxicol Cur Res 5: 022

Received: September 15, 2021; Accepted: September 27, 2021; Published: October 04, 2021

Copyright: ( 2021 Sasidharan S, et al. This is an open-access article distributed under the terms of the Creative Commons Attribution License, which permits unrestricted use, distribution, and reproduction in any medium, provided the original author and source are credited. application, most erythema and edema formed on the sites applied with Pankajakasthuri orthoherb cream/thermagel disappeared. The primary skin irritation index of Pankajakasthuri orthoherb cream/thermagel was found to be 0.38 , which appeared to be coming under the category of non-irritant (0-0.4) in rabbits. Hence, Pankajakasthuri orthoherb cream/thermagel could be considered as non-irritant and safe on rabbit skin. Thus, the topical Pankajakasthuri orthoherb cream/thermagel was safe to apply on the skin without irritation.

Keywords: Anti-inflammatory, analgesic, Dermal irritation, Pankajakasthuri orthoherb cream/thermagel, Skin, Topical application

\section{Introduction}

The skin is the largest human organ, and it serves primarily as a protective covering for the body. The skin is made up of multiple layers and performs a variety of vital functions for survival. The skin's function includes protecting the body from environmental hazards such as toxic or corrosive chemicals. When the skin is exposed to a chemical, a variety of adverse health effects can occur. In general, three types of chemical-skin interactions can occur: direct skin effects, immune-mediated skin effects, and systemic effects [1]. Skin irritation and corrosion refer to localized toxic effects resulting from a topical contact of the skin to a substance. Evaluation of skin irritation due to a chemical or pharmaceutical compound is necessary considering its safe usage. In vivo and in vitro tests are available to determine the risk of irritation due to the contact between these compounds and human skin. Conducting the skin irritating effects of chemicals on experimental animals provides the public with information regarding all the potential risks during the exposure. The most commonly used test is the rabbit skin irritation test described in the OECD test guideline 404, which was initially described by Draize et. al. 1944 [2]. In skin irritation test, the test substances (either raw materials or finished products) were applied to the shaved skin of rabbits and then observed for a period of 14 days for any signs of skin irritation. Signs of skin irritation mainly include the development of a rash, inflammation, swelling, scaling, and abnormal tissue growth in the affected area. A score of skin reactions is made based on physiological observations. If a chemical or compound is demonstrated to be non-toxic to the skin in animals or clinical trials, its use should be approved.

The use of herbs and herbal medicines is as old as human civilization, and it has a crucial role in health and disease management. Over time and with proper supporting scientific data and clinical trials, traditional treatment systems such as herbal medicine can be reclassified as a practice of conventional medicine. All age groups now have a more positive social outlook on herbal medicine [3]. It is widely held that Complementary and Alternative Medicine (CAM) allows people to be more involved in their care, control or mitigate the negative effects of conventional medicine, and find harmony with their culture or philosophies [4]. Patients frequently seek all possible options for receiving medical care benefits while evading adverse reactions [ $\underline{5}$ ]. Pain is one of the most common conditions for which grownups use traditional or alternative systems. This includes joint pain or musculoskeletal pain, as well as specific diseases like arthritis or migraine. 
Citation: Sasidharan S, Nair JH (2021) Dermal irritation study of Pankajakasthuri orthoherb cream/thermagel, a potent polyherbal antiinflammatory and analgesic formulation for topical application in healthy New Zealand white rabbits. J Toxicol Cur Res 5: 022.

Although pain is a physiological response to actual tissue injury, it can become chronic in some cases (such as musculoskeletal pain or special conditions like arthritis) and cause biological changes in the central nervous system or peripheral tissues. Chronic pain can be incapacitating and places a significant social and economic burden on the healthcare system [6]. Such patients, particularly the elderly, must either live with chronic pain or seek alternative therapeutic options.

Recently Pankajakasthuri Herbals India Pvt. Ltd., Poovachal, Kattakada, Thiruvananthapuram has formulated Pankajakasthuri orthoherb cream/thermagel which can provide relief from severe muscle and joint pain. This formulation contains 21 active ayurvedic ingredients like Adathoda vasica, Aegle marmelos, Ricinus communis, Azadirecta indica, Sida retusa, Tragia involucrata, etc., that could increase blood circulation/blood pooling through vasodilation and could relieve pain through counter stimulation. The specialty of Pankajakasthuri orthoherb cream/thermagel is that it could provide the same result as applying a traditional Ayurvedic kizhi. However, investigations are needed to validate the effectiveness and safety of this polyherbal mixture before it can be used in clinical practice and incorporated into treatment guidelines. Hence, the purpose of this study is to evaluate and validate the safety of Pankajakasthuri orthoherb cream/thermagel on rabbit skin.

\section{Materials and methods}

\section{Test Drug (Pankajakasthuri orthoherb cream/thermagel)}

Pankajakasthuri orthoherb cream/thermagel, a herbal-based cream/gel for topical administration, is the test drug. The product is is produced at Pankajakasthuri Herbals India Pvt. Ltd. at Poovachal, Kattakada, Thiruvananthapuram, Kerala, India, on a Good Manufacturing Practices-approved production line.

\section{Experimental animals}

Healthy, adult white New Zealand rabbits weighing (2-2.4 kg) were obtained from Small Animal Breeding Station, Mannuthy, Thrissur, Kerala, India. Animals were grouped and housed under normal laboratory conditions with temperature of $22 \pm 3^{\circ} \mathrm{C}$ and $50 \%$ to $70 \%$ relative humidity with a 12-hour light-dark cycle. An acclimatization period of 7 days to the laboratory conditions prior to the beginning of the experiment was provided in order to adjust the new environment and to overcome stress incurred during their transit. Approval to carry out this particular study was obtained from the Institutional Animal Ethics Committee of CARe KERALAM (Approval No. CKL/TOX/ IAEC/2021-1/149). All animal experimental protocols followed the guidelines of the committee for the purpose of controlling and supervising animal experiments, Ministry of Forest and Environment, Government of India. Throughout the acclimatization and study period, the animals were fed ad libitum.

\section{Experimental design}

The test was carried out by employing OECD guideline 404 [7]. Approximately $24 \mathrm{~h}$ before the test, fur was clipped on both sides of the spinal column (approximately $10 \mathrm{~cm} \times 15 \mathrm{~cm}$ ). Pankajakasthuri orthoherb cream/thermagel was used as test material. The absorbent gauze saturated with sterile RO water was used as a negative control. Three animals were used for the test. All the application sites were covered with a $2.5 \mathrm{~cm} \times 2.5 \mathrm{~cm}$ sterile absorbent gauze patch and then wrapped with a bandage for $4 \mathrm{~h}$. At the end of the contact time, the dressings were removed and marked the positions of the sites with permanent ink. The residual test material was removed with lukewarm water and carefully dried.

\section{Single-exposure test}

In a single application test, the appearance of each application site at $1 \pm 0.1 \mathrm{~h}, 24 \pm 2 \mathrm{~h}, 48 \pm 2 \mathrm{~h}$ and $72 \pm 2 \mathrm{~h}$ following removal of the patches were recorded. The extended observation was used if there were persistent lesions to evaluate the reversibility or irreversibility of the lesions for up to 14 days.

\section{Repeated-exposure test}

A repeated exposure test was carried out after the completion of the single-exposure test. For the repeated-exposure test, the test sample was applied for three consecutive days and appearances of the application site at $1 \pm 0.1 \mathrm{~h}$ after removal of the patches and immediately prior to the next application was recorded. After the last exposure, the appearance of each application site at $1 \pm 0.1 \mathrm{~h}, 24 \pm 2 \mathrm{~h}, 48 \pm 2 \mathrm{~h}$ and $72 \pm 2 \mathrm{~h}$ were noted following removal of the patches. The extended observation was conducted if there were persistent lesions to evaluate the reversibility or irreversibility of the lesions for up to 14 days.

All animals were observed daily in the morning and afternoon for clinical signs and mortality during the study period. The bodyweight of each rabbit was recorded prior to treatment on Day 1 and followed by $7^{\text {th }}$ and $14^{\text {th }}$ day of the study. The quantity of food and water consumed by rabbits in each cage was measured and recorded weekly from the day of commencement of treatment. Dermal reactions were graded and recorded according to the scoring system mentioned in (Table 1).

\begin{tabular}{|c|c|}
\hline Reaction & Irritation score \\
\hline \multicolumn{2}{|l|}{ Erythema and Eschar Formation } \\
\hline No erythema & $\mathbf{0}$ \\
\hline Very slight erythema (barely perceptible) & 1 \\
\hline Well defined erythema & 2 \\
\hline Moderate to severe erythema & 3 \\
\hline $\begin{array}{l}\text { Severe erythema (beet redness) to eschar formation preventing } \\
\text { grading of erythema }\end{array}$ & 4 \\
\hline \multicolumn{2}{|l|}{ Edema formation } \\
\hline No edema & $\mathbf{0}$ \\
\hline Very slight edema (barely perceptible) & 1 \\
\hline Slight edema (edges of area well raised) & 2 \\
\hline Moderate edema (raised approx. $1 \mathrm{~mm}$ ) & 3 \\
\hline $\begin{array}{l}\text { Severe edema (raised more than } 1 \mathrm{~mm} \text { and extending } 4 \text { beyond } \\
\text { area of exposure) }\end{array}$ & 4 \\
\hline Maximal possible score for irritation & 8 \\
\hline $\begin{array}{c}\text { *Other adverse changes in the skin sites shall be recorded and } \\
\text { reported }\end{array}$ & \\
\hline
\end{tabular}

Table 1: Scoring system for skin reaction.

The dermal irritation scores were evaluated as per (Table 2) in conjunction with the nature and severity of lesions, and their reversibility or lack of reversibility.

\section{Statistical analysis}

Data on irritation were presented as visual scores based on the Draize method [2] of erythema and edema grading system, and 
Citation: Sasidharan S, Nair JH (2021) Dermal irritation study of Pankajakasthuri orthoherb cream/thermagel, a potent polyherbal antiinflammatory and analgesic formulation for topical application in healthy New Zealand white rabbits. J Toxicol Cur Res 5: 022.

combined index was calculated. Data obtained from body weight measurements, water and food uptake were expressed as mean \pm SD.

\begin{tabular}{|c|c|}
\hline Mean Score & Response category \\
\hline 0.0 to 0.4 & Negligible/Non-irritant \\
\hline 0.5 to 1.9 & Slight \\
\hline 2.0 to 4.9 & Moderate \\
\hline 5.0 to 8.0 & Severe \\
\hline
\end{tabular}

Table 2: Primary or cumulative skin irritation index categories in rabbit.

\section{Results}

The results obtained from a single-exposure dermal irritation study in rabbits are presented in (Table 3 ).

\begin{tabular}{|c|c|c|c|c|c|c|c|c|c|}
\hline \multirow{4}{*}{$\begin{array}{l}\text { Time after } \\
\text { treatment and } \\
\text { Lesion Scores }\end{array}$} & \multicolumn{6}{|c|}{ Rabbit Numbers } & \multirow{2}{*}{\multicolumn{2}{|c|}{$\begin{array}{c}\text { Mean } \\
\text { score }\end{array}$}} & \multirow{4}{*}{ Figures } \\
\hline & \multirow{2}{*}{\multicolumn{2}{|c|}{$\frac{1}{\text { Female }}$}} & \multirow{2}{*}{\multicolumn{2}{|c|}{$\frac{2}{\text { Male }}$}} & \multirow{2}{*}{\multicolumn{2}{|c|}{$\begin{array}{c}3 \\
\text { Male }\end{array}$}} & & & \\
\hline & & & & & & & \multirow{2}{*}{$\mathbf{T}$} & \multirow{2}{*}{$\mathbf{C}$} & \\
\hline & $\mathbf{T}$ & C & $\mathbf{T}$ & C & $\mathbf{T}$ & C & & & \\
\hline $\begin{array}{c}\mathbf{1 ~ h} \\
\text { Erythema Score }\end{array}$ & 0 & 0 & 0 & 0 & 0 & 0 & \multirow[b]{2}{*}{0} & \multirow[b]{2}{*}{0} & \\
\hline Edema Score & 0 & 0 & 0 & 0 & 0 & 0 & & & \\
\hline $\begin{array}{l}\mathbf{2 4} \mathbf{h} \\
\text { Erythema Score }\end{array}$ & 0 & 0 & 0 & 0 & 0 & 0 & \multirow{2}{*}{0} & \multirow{2}{*}{0} & \\
\hline Edema Score & 0 & 0 & 0 & 0 & 0 & 0 & & & \\
\hline $\begin{array}{l}\quad 48 \text { h } \\
\text { Erythema Score }\end{array}$ & 0 & 0 & 0 & 0 & 0 & 0 & & & \\
\hline Edema Score & 0 & 0 & 0 & 0 & 0 & 0 & & & \\
\hline $\begin{array}{c}\mathbf{7 2} \mathbf{h} \\
\text { Erythema Score }\end{array}$ & 0 & 0 & 0 & 0 & 0 & 0 & & & \\
\hline Edema Score & 0 & 0 & 0 & 0 & 0 & 0 & 0 & 0 & \\
\hline $\begin{array}{c}7 \text { Days } \\
\text { Erythema Score }\end{array}$ & 0 & 0 & 0 & 0 & 0 & 0 & & & \\
\hline Edema Score & 0 & 0 & 0 & 0 & 0 & 0 & 0 & 0 & \\
\hline $\begin{array}{l}14 \text { Days } \\
\text { Erythema Score }\end{array}$ & 0 & 0 & 0 & 0 & 0 & 0 & & & \\
\hline Edema Score & 0 & 0 & 0 & 0 & 0 & 0 & 0 & 0 & t \\
\hline
\end{tabular}

Table 3: Dermal reaction scores for single exposure test of Pankajakasthuri orthoherb cream/thermagel.

Primary Irritation Index $=0$

*T-Test, C- Control

Any visible skin irritation and inflammation (edema and erythema) was not observed in rabbits treated with a single application of
Pankajakasthuri orthoherb cream/thermagel during the study period as compared with the control. The combined irritation index score for acute single exposure dermal irritation was found to be ' 0 '.

The observations on erythema and edema that occurred during the repeated exposure test of Pankajakasthuri orthoherb cream/thermagel in rabbits are presented in (Table 4).

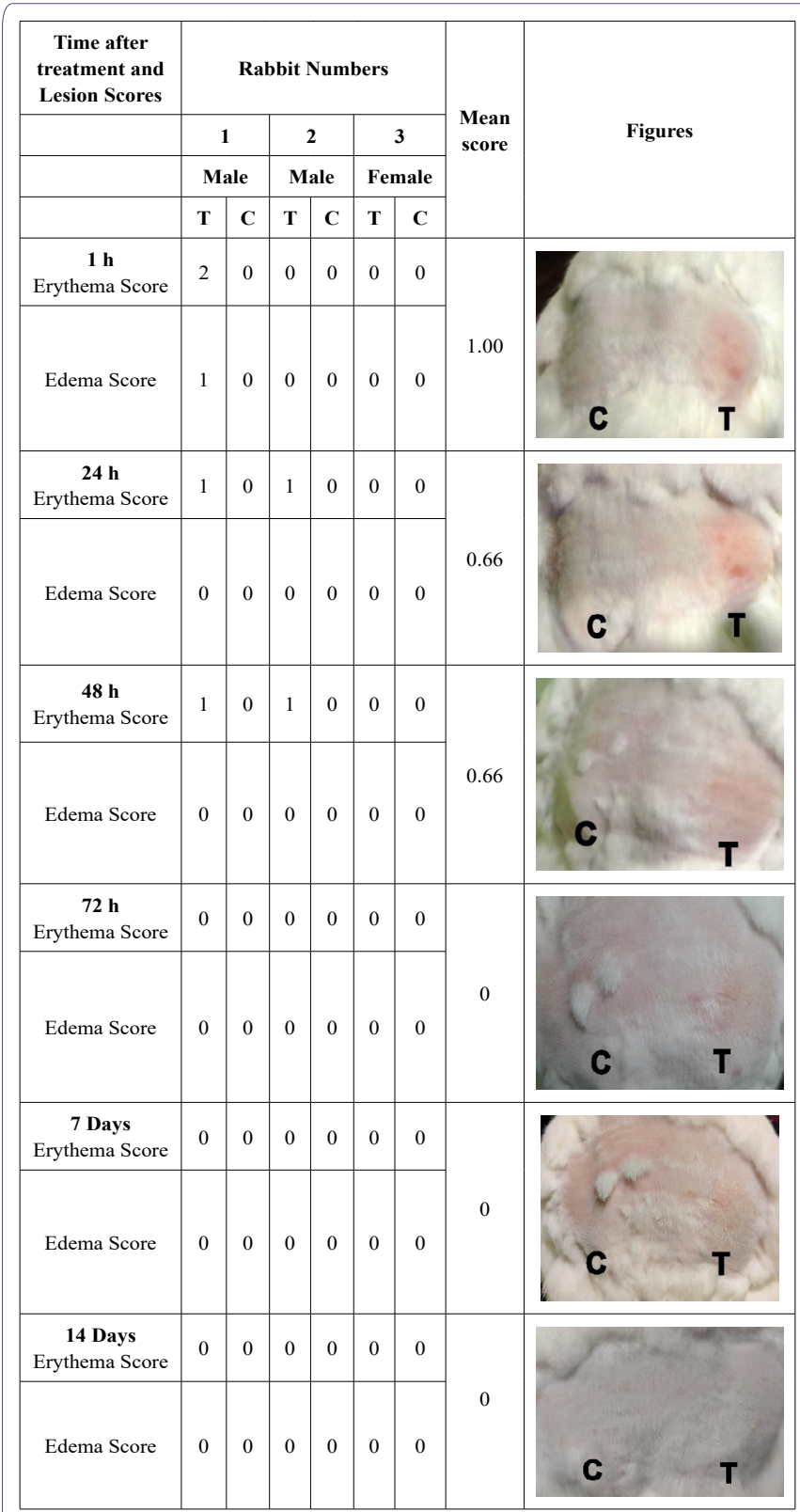

Table 4: Dermal reaction scores for repeated exposure test of Pankajakasthuri orthoherb cream/thermagel.

Primary irritation index $(\mathrm{PII})=0.38$.

*T-Test, C- Control

Both parameters were calculated to obtain the Primary irritation index (PII). On the final (third) day of application, erythema was observed on the skin sites applied with Pankajakasthuri orthoherb cream/thermagel in 2 out of 3 rabbits compared with control sites. However, after $48 \mathrm{~h}$ of final application, most erythemas found on sites applied with Pankajakasthuri orthoherb cream/thermagel 
Citation: Sasidharan S, Nair JH (2021) Dermal irritation study of Pankajakasthuri orthoherb cream/thermagel, a potent polyherbal antiinflammatory and analgesic formulation for topical application in healthy New Zealand white rabbits. J Toxicol Cur Res 5: 022.

disappeared or reduced in severity (barely perceptible erythema). Almost no erythema persisted $72 \mathrm{~h}$ after the last application of Pankajakasthuri orthoherb cream/thermagel.

The occurrences of edema on sites applied with Pankajakasthuri orthoherb cream/thermagel were noted on the final day of application compared with control sites. Edema with a score of 1 (very slight edema) was found in 1 out of 3 on sites with Pankajakasthuri orthoherb cream/thermagel at $1 \mathrm{~h}$ after the final application. At 24 hours after the final application, all edemas disappeared.

The primary irritation index score of Pankajakasthuri orthoherb cream/thermagel and sterile RO water (control) was calculated according to the Draize method of classification [2] as shown in (Table 4). The primary or cumulative skin irritation index of Pankajakasthuri orthoherb cream/thermagel was found to be 0.38 and that of sterile RO water was 0 . Hence, Pankajakasthuri orthoherb cream/thermagel comes in the category of non-irritant (0-0.4) in rabbits.

\section{Bodyweight, food and water consumption trends}

In the present study, no treatment-related changes in body weight were noted in rabbits (Tables $5 \& 6$ ).

\begin{tabular}{|c|c|c|c|c|c|c|}
\hline \multirow{2}{*}{ Group } & \multirow{2}{*}{ Sex } & \multicolumn{3}{|c|}{ Body weight (g) } & \multicolumn{2}{c|}{ Body weight gain (\%) } \\
\cline { 3 - 7 } & & Day 1 & Day 7 & Day 14 & $\mathbf{1 - 7}$ days & $\mathbf{1 - 1 4 ~ d a y s ~}$ \\
\hline 1 & Female & 2.41 & 2.54 & 2.58 & 5.4 & 4.1 \\
\hline 2 & Male & 2.12 & 2.23 & 2.25 & 5.2 & 3.8 \\
\hline 3 & Male & 2.00 & 2.11 & 2.11 & 5.3 & 3.5 \\
\hline
\end{tabular}

Table 5: Body weight and Percentage weight gain in rabbits after single exposure treatment.

\begin{tabular}{|c|c|c|c|c|c|c|}
\hline \multirow{2}{*}{ Group } & \multirow{2}{*}{ Sex } & \multicolumn{3}{|c|}{ Body weight (g) } & \multicolumn{2}{c|}{ Body weight gain (\%) } \\
\cline { 3 - 7 } & & Day 1 & Day 7 & Day 14 & $\mathbf{1 - 7}$ days & $\mathbf{1 - 1 4}$ days \\
\hline 1 & Male & 2.29 & 2.30 & 2.42 & 0.4 & 1.6 \\
\hline 2 & Male & 2.26 & 2.28 & 2.40 & 0.9 & 2.0 \\
\hline 3 & Female & 2.88 & 2.97 & 2.99 & 3.1 & 2.6 \\
\hline
\end{tabular}

Table 6: Body weight and Percentage weight gain in rabbits after repeated exposure treatment.

No significant differences were noted in food and water consumption throughout the experiment (Tables 7 to 10).

\begin{tabular}{|c|c|c|c|c|}
\hline \multirow{2}{*}{ Group } & \multirow{2}{*}{ Sex } & \multicolumn{3}{|c|}{ Food intake (g) mean \pm SD } \\
\cline { 3 - 5 } & & $\mathbf{1 - 7}$ days & $\mathbf{8 - 1 4}$ days & $\mathbf{1 - 1 4}$ days \\
\hline 1 & Female & $83.57 \pm 3.78$ & $84.29 \pm 4.50$ & $83.93 \pm 4.01$ \\
\hline 2 & Male & $92.14 \pm 6.36$ & $85.00 \pm 4.08$ & $88.57 \pm 6.33$ \\
\hline 3 & Male & $83.57 \pm 3.78$ & $83.57 \pm 4.76$ & $83.50 \pm 4.13$ \\
\hline
\end{tabular}

Table 7: Mean food intake during single exposure treatment

\begin{tabular}{|c|c|c|c|c|}
\hline \multirow{2}{*}{ Group } & \multirow{2}{*}{ Sex } & \multicolumn{3}{|c|}{ Food intake (g) mean \pm SD } \\
\cline { 3 - 5 } & & $\mathbf{1 - 7}$ days & $\mathbf{8 - 1 4}$ days & $\mathbf{1 - 1 4}$ days \\
\hline 1 & Male & $87.14 \pm 5.67$ & $84.29 \pm 4.50$ & $85.71 \pm 5.14$ \\
\hline 2 & Male & $86.43 \pm 5.56$ & $85.00 \pm 5.77$ & $85.71 \pm 5.50$ \\
\hline 3 & Female & $87.86 \pm 7.56$ & $84.29 \pm 4.50$ & $86.07 \pm 6.26$ \\
\hline
\end{tabular}

Table 8: Mean food intake during repeated exposure treatment.

\begin{tabular}{|c|c|c|c|c|}
\hline \multirow{2}{*}{ Group } & \multirow{2}{*}{ Sex } & \multicolumn{3}{|c|}{ Water intake (mI) mean \pm SD } \\
\cline { 3 - 5 } & & $\mathbf{1 - 7}$ days & $\mathbf{8 - 1 4}$ days & $\mathbf{1 - 1 4}$ days \\
\hline 1 & Female & $217.14 \pm 14.96$ & $224.29 \pm 17.18$ & $220.71 \pm 15.92$ \\
\hline 2 & Male & $242.14 \pm 13.50$ & $228.5 \pm 15.74$ & $235.36 \pm 15.75$ \\
\hline 3 & Male & $229.88 \pm 18.26$ & $232.14 \pm 9.94$ & $231.07 \pm 14.17$ \\
\hline
\end{tabular}

Table 9: Mean water intake of rabbits during single exposure treatment.

\begin{tabular}{|c|c|c|c|c|}
\hline \multirow{2}{*}{ Group } & \multirow{2}{*}{ Sex } & \multicolumn{3}{|c|}{ Water intake (ml) mean \pm SD } \\
\cline { 3 - 5 } & & $\mathbf{1 - 7}$ days & $\mathbf{8 - 1 4}$ days & $\mathbf{1 - 1 4}$ days \\
\hline 1 & Male & $234.29 \pm 19.88$ & $231.43 \pm 15.74$ & $232.86 \pm 17.29$ \\
\hline 2 & Male & $221.43 \pm 13.45$ & $227.86 \pm 15.77$ & $224.64 \pm 14.47$ \\
\hline 3 & Female & $231.43 \pm 17.01$ & $235.00 \pm 9.57$ & $233.21 \pm 13.39$ \\
\hline
\end{tabular}

Table 10: Mean water intake of rabbits during repeated exposure treatment.

\section{Discussion}

Herbs are presumed to be a major source of potentially useful constituents for the development of new therapeutic agents because they are generally safe and have few or no side effects. Compared to ointment, topical application of creams/gels at pathological sites provides significant advantages in drug release directly to the site of action [8,9]. As active ingredients, extracts of herbs with specific medicinal properties can be included in this dosage form. Adhatoda vasica [10,11], Azadirachta indica [12-14], Aegle marmelos $[15,16]$, Ricinus communis $[17,18]$, Sida retusa $[19,20]$ and Tragia involucrata $[21,22]$ plants have been studied for their anti-inflammatory and analgesic properties. However, their application in the raw form on the skin surface is difficult. Therefore, the extracts of these plants were developed in the form of a gel formulation. Risk assessment is a function of hazard and exposure data. It is the recommended stepwise testing approach for new substances introduced to the market for developing scientifically sound data on the irritation of the substance [23]. Herbal products are thought to be safe for longer periods of time, but the scarcity of toxicological studies on medicinal plants raises legitimate concerns about the potentially toxic effects of long-term use [24]. However, quality control for the efficacy and safety of herbal products is critical, and quality control tests for these preparations must be performed.

Allergy is characterized by edema and erythema and is caused by hypersensitivity of the skin or an excessive immune response to an antigen [25]. Edema is a buildup of excess serious fluid between tissue cells, whereas erythema is redness of the skin or mucous membranes caused by hyperemia of superficial capillaries [26]. In the present study, single application of Pankajakasthuri orthoherb cream/ thermagel in rabbits did not show any dermal irritation or reactions like erythema and edema. In a repeated exposure study, application of Pankajakasthuri orthoherb cream/thermagel caused erythema and edema in some animals; however, by $72 \mathrm{~h}$ after final application, most erythema and edema found on the applied sites had disappeared. Primary or cumulative skin irritation index of Pankajakasthuri orthoherb cream/thermagel was found to be 0.38 which appeared to be coming under the category of non-irritant $(0-0.4)$ in rabbits.

Earlier works conducted on polyherbal formulations containing ethanolic extract of Azadirachta indica, and Adhatoda vasica reported no skin irritation after performing patch test in human volunteers thus, confirming the safety of these formulations on human skin [27]. 
Citation: Sasidharan S, Nair JH (2021) Dermal irritation study of Pankajakasthuri orthoherb cream/thermagel, a potent polyherbal antiinflammatory and analgesic formulation for topical application in healthy New Zealand white rabbits. J Toxicol Cur Res 5: 022.

Evaluation of skin irritation potential of a herbal anti-inflammatory gel using Aegle marmelos fruit extracts indicated that the particular gel did not produce irritation, redness, or edema on application and was free from dermatological reaction [28].

There was no mortality in rabbits during the 14 days study period. Loss of body weight is an important marker of toxicity. Drastic toxicity or interference with absorption of nutrients will be reflected in body weight reduction [29]. In the current study, there was no significant difference in the body weight of the rabbits. As a result, it is safe to assume that Pankajakasthuri orthoherb cream/thermagel has no tendency to cause tissue destruction and does not appear to interfere with nutrient absorption. Food and water consumption in the treated and control groups were remarkably similar, with no significant differences.

\section{Conclusion}

The results of the study revealed that Pankajakasthuri orthoherb cream/thermagel was not irritant to rabbit skin in single and repeated application studies. Following a 14-day observation period, there were no significant changes in body weight, food and water intake. According to the findings, the Pankajakasthuri orthoherb cream/thermagel is safe for long-term topical use.

\section{Acknowledgement}

The authors express their gratitude to "Aadhyathma Chinthalayesan" of Chinthala Ashram, Pothencode, Trivandrum, Kerala, India, for his compassion and blessings. We are grateful to Pankajakasthuri Herbal Research Foundation, Kattakada, Thiruvananthapuram, Kerala, India, and Pankajakasthuri Herbals India Pvt. Ltd Poovachal, Kattakada, Thiruvananthapuram, Kerala, India, for helping us with the research. We also like to express our gratitude to all of the Directors and employees of Pankajakasthuri Herbal Research Foundation and Pankajakasthuri Herbals India Pvt. Ltd for their support in completing this project. The authors would like to express their gratitude to Dr. Sithara MS (MVSc.), Small Animal Research Centre, Department of Toxicology and Pharmacology, CARe KERALA, Koratty, Thrissur, Kerala, India, for her valuable technical assistance to conduct the animal experiments.

\section{References}

1. Anderson SE, Meade J (2014) Potential health effects associated with dermal exposure to occupational chemicals. Environmental health insights 8 $51-62$.

2. Draize JH, Woodard G, Calvery HO (1944) Methods for the study of irritation and toxicity of substances applied topically to the skin and mucous membranes. J Pharmacol Exp Ther 82: 377-390.

3. Eisenberg DM, Davis RB, Ettner SL, Appel S, Wilkey S, et al. (1998) Trends in Alternative Medicine Use in the United States, 1990-1997: Results of a Follow-up National Survey. JAMA 280:1569-1575.

4. Gentz BA (2001) Alternative Therapies for the Management of Pain in Labor and Delivery. Clin Obstet Gynecol 44: 704-732.

5. Ernst E, Willoughby M, Weihmayr TH (1995) Nine Possible Reasons for Choosing Complementary Medicine. Perfusion 11: 356-359.

6. NCCIH (2016) Nonpharmacologic Management of Pain. NCCIH, Bethesda, Maryland, USA

7. OECD (2002) Test no. 404: Acute dermal irritation/corrosion. OECD, Paris, France.

8. Avinash S, Gowda DV, Suresh J, Aravind RAS, Srivastava A, et al. (2016) Formulation and evaluation of topical gel using Eupatorium glandulosum michx. for wound healing activity. Pharm Lett 8: 255-266.
9. Patel H, Panchal MS, Shah S, Vadalia KR (2012) formulation and evaluation of transdermal gel of sildenafil citrate. Int J Pharm Res Allied Sci 1: 103-118.

10. Mulla W, More S, Jamge SB, Pawar A, Kazi M, et al. (2010) Evaluation of antiinflammatory and analgesic activities of ethanolic extract of roots Adhatoda vasica Linn. International Journal of PharmTech Research 2: 1364-1368.

11. Belemkar S (2013) Evaluation of Anti-inflammatory and analgesic activities of methanolic extract of Adhatoda vasica and Mentha piperita Linn. Inventi Rapid: Ethnopharmacology 1.

12. Vandana KS, Agrawal U, Hansa D, Jagadish A (2015) Analgesic, Anti-inflammatory and Anti-Pyretic Effects of Azadirachta indica (Neem) Leaf Extract in Albino Rats. International Journal of Science and Research 4: $713-721$

13. Naik MR, Bhattacharya A, Behera R, Agrawal D, Dehury S, et al. (2014) Study of anti-inflammatory effect of neem seed oil (Azadirachta indica) on infected albino rats. J Health Res Rev 1: 66-9.

14. Dr. Jagadeesh K (2014) Anti-Inflammatory Effect of Azadirachta Indica (Neem) In Albino Rats-An Experimental Study. IOSR Journal of Pharmacy (IOSRPHR) 4: 34-38.

15. Arul V, Miyazaki S, Dhananjayan R (2005) Studies on the anti-inflammatory, antipyretic and analgesic properties of the leaves of Aegle marmelos Corr. J Ethnopharmacol 96: 159-63.

16. Benni JM, Jayanthi MK, Suresha RN (2011) Evaluation of the anti-inflammatory activity of Aegle marmelos (Bilwa) root. Indian Journal of Pharmacology 43: 393-397

17. Mallika RI, Subramanin MV (2006) Anti-inflammatory and free radical scavenging activity of Ricinus communis root extract. Journal of ethnopharmacology 103: 478-80

18. Taur DJ, Waghmare MG, Bandal RS, Patil RY (2011) Antinociceptive activity of Ricinus communis L. leaves. Asian Pacific journal of tropical biomedicine 1: 139-141.

19. Franzotti EM, Santos CV, Rodrigues HM, Mourão RH, Andrade MR, et al. (2000) Anti-inflammatory, analgesic activity and acute toxicity of Sida cordifolia L. (Malva-branca). J Ethnopharmacol 72: 273-277.

20. Kanth VR, Diwan PV (1999) Analgesic, antiinflammatory and hypoglycaemic activities of Sida cordifolia. Phytother Res 13: 75-7.

21. Dhara AK, Suba V, Sen T, Pal S, Chaudhuri AK (2000) Preliminary studies on the anti-inflammatory and analgesic activity of the methanolic fraction of the root extract of Tragia involucrata Linn. J Ethnopharmacol 72: 265268 .

22. Alimuzzaman Md, Muniruddin A (2007) Analgesic Activity of Tragia involucrata. Dhaka University Journal of Pharmaceutical Sciences 4 10.3329 .

23. Jianzhong W, Zhiyuan L, Feifei S, Shusheng T, Suxia Z, et al. (2017) Evaluation of dermal irritation and skin sensitization due to vitacoxib. Toxicology Reports 4: 287-290.

24. Ermias L, Solomon T, Selam G, Kassahun D, Tizazu Z, et al (2019) Phytochemical analysis and evaluation of skin irritation, acute and sub-acute toxicity of Cymbopogon citratus essential oil in mice and rabbits. Toxicology Reports 6: 1289-1294.

25. James O, Sunday AB (2014) Evaluation of Acute Dermal Irritation and Wound Contraction by Gymnema Sylvestre and Datura Metel Extracts in Rats. American Journal of Biomedical and Life Sciences 2: 83-88.

26. Gatne M, Tambe K, Ravikanth K (2015) Acute dermal irritation study of Polyherbal gel Mastilep in rabbits. Int. J. Pharm. Sci. Res 6: 3473.

27. Randive BM, Ganesh DW, Bhinge KS, Somnath S (2018) Formulation and evaluation of polyherbal gel containing extracts of Azadirachta indica Adhatoda vasica, Piper betle, Ocimum tenuiflorum and Pongamia pinnata. Journal of Research in Pharmacy 23: 44-54. 
Citation: Sasidharan S, Nair JH (2021) Dermal irritation study of Pankajakasthuri orthoherb cream/thermagel, a potent polyherbal antiinflammatory and analgesic formulation for topical application in healthy New Zealand white rabbits. J Toxicol Cur Res 5: 022.

- Page 6 of 6 -

28. Mahendra AG, Rasika DB (2019) Formulation and Evaluation of Topical Anti-Inflammatory Herbal Gel. Asian Journal of Pharmaceutical and Clinical Research 12: 252-255.
29. Banerjee S, Chattopadhyay P, Ghosh A, Pathak MP, Singh S, et al. (2013) Acute dermal irritation, sensitization, and acute toxicity studies of a transdermal patch for prophylaxis against $( \pm$ ) anatoxin-A poisoning. Int $\mathrm{J}$ Toxicol 32: 308-313. 


\section{$\mathbb{d}$ \\ Hнram}

Advances In Industrial Biotechnology | ISSN: 2639-5665

Advances In Microbiology Research | ISSN: 2689-694X

Archives Of Surgery And Surgical Education | ISSN: 2689-3126

Archives Of Urology

Archives Of Zoological Studies | ISSN: 2640-7779

Current Trends Medical And Biological Engineering

International Journal Of Case Reports And Therapeutic Studies | ISSN: 2689-310X

Journal Of Addiction \& Addictive Disorders | ISSN: 2578-7276

Journal Of Agronomy \& Agricultural Science | ISSN: 2689-8292

Journal Of AIDS Clinical Research \& STDs | ISSN: 2572-7370

Journal Of Alcoholism Drug Abuse \& Substance Dependence | ISSN: 2572-9594

Journal Of Allergy Disorders \& Therapy | ISSN: 2470-749X

Journal Of Alternative Complementary \& Integrative Medicine | ISSN: 2470-7562

Journal Of Alzheimers \& Neurodegenerative Diseases | ISSN: 2572-9608

Journal Of Anesthesia \& Clinical Care | ISSN: 2378-8879

Journal Of Angiology \& Vascular Surgery | ISSN: 2572-7397

Journal Of Animal Research \& Veterinary Science | ISSN: 2639-3751

Journal Of Aquaculture \& Fisheries | ISSN: 2576-5523

Journal Of Atmospheric \& Earth Sciences | ISSN: 2689-8780

Journal Of Biotech Research \& Biochemistry

Journal Of Brain \& Neuroscience Research

Journal Of Cancer Biology \& Treatment | ISSN: 2470-7546

Journal Of Cardiology Study \& Research | ISSN: 2640-768X

Journal Of Cell Biology \& Cell Metabolism | ISSN: 2381-1943

Journal Of Clinical Dermatology \& Therapy | ISSN: 2378-8771

Journal Of Clinical Immunology \& Immunotherapy | ISSN: 2378-8844

Journal Of Clinical Studies \& Medical Case Reports | ISSN: 2378-8801

Journal Of Community Medicine \& Public Health Care | ISSN: 2381-1978

Journal Of Cytology \& Tissue Biology | ISSN: 2378-9107

Journal Of Dairy Research \& Technology | ISSN: 2688-9315

Journal Of Dentistry Oral Health \& Cosmesis | ISSN: 2473-6783

Journal Of Diabetes \& Metabolic Disorders | ISSN: 2381-201X

Journal Of Emergency Medicine Trauma \& Surgical Care | ISSN: 2378-8798

Journal Of Environmental Science Current Research | ISSN: 2643-5020

Journal Of Food Science \& Nutrition | ISSN: 2470-1076

Journal Of Forensic Legal \& Investigative Sciences | ISSN: 2473-733X

Journal Of Gastroenterology \& Hepatology Research | ISSN: 2574-2566
Journal Of Genetics \& Genomic Sciences | ISSN: 2574-2485

Journal Of Gerontology \& Geriatric Medicine | ISSN: 2381-8662

Journal Of Hematology Blood Transfusion \& Disorders | ISSN: 2572-2999

Journal Of Hospice \& Palliative Medical Care

Journal Of Human Endocrinology | ISSN: 2572-9640

Journal Of Infectious \& Non Infectious Diseases | ISSN: 2381-8654

Journal Of Internal Medicine \& Primary Healthcare | ISSN: 2574-2493

Journal Of Light \& Laser Current Trends

Journal Of Medicine Study \& Research | ISSN: 2639-5657

Journal Of Modern Chemical Sciences

Journal Of Nanotechnology Nanomedicine \& Nanobiotechnology | ISSN: 2381-2044 Journal Of Neonatology \& Clinical Pediatrics | ISSN: 2378-878X

Journal Of Nephrology \& Renal Therapy | ISSN: 2473-7313

Journal Of Non Invasive Vascular Investigation | ISSN: 2572-7400

Journal Of Nuclear Medicine Radiology \& Radiation Therapy | ISSN: 2572-7419

Journal Of Obesity \& Weight Loss | ISSN: 2473-7372

Journal Of Ophthalmology \& Clinical Research | ISSN: 2378-8887

Journal Of Orthopedic Research \& Physiotherapy | ISSN: 2381-2052

Journal Of Otolaryngology Head \& Neck Surgery | ISSN: 2573-010X

Journal Of Pathology Clinical \& Medical Research

Journal Of Pharmacology Pharmaceutics \& Pharmacovigilance | ISSN: 2639-5649

Journal Of Physical Medicine Rehabilitation \& Disabilities | ISSN: 2381-8670

Journal Of Plant Science Current Research | ISSN: 2639-3743

Journal Of Practical \& Professional Nursing | ISSN: 2639-5681

Journal Of Protein Research \& Bioinformatics

Journal Of Psychiatry Depression \& Anxiety | ISSN: 2573-0150

Journal Of Pulmonary Medicine \& Respiratory Research | ISSN: 2573-0177

Journal Of Reproductive Medicine Gynaecology \& Obstetrics | ISSN: 2574-2574

Journal Of Stem Cells Research Development \& Therapy | ISSN: 2381-2060

Journal Of Surgery Current Trends \& Innovations | ISSN: 2578-7284

Journal Of Toxicology Current Research | ISSN: 2639-3735

Journal Of Translational Science And Research

Journal Of Vaccines Research \& Vaccination | ISSN: 2573-0193

Journal Of Virology \& Antivirals

Sports Medicine And Injury Care Journal | ISSN: 2689-8829

Trends In Anatomy \& Physiology | ISSN: 2640-7752

Submit Your Manuscript: https://www.heraldopenaccess.us/submit-manuscript 